\title{
ANALISIS STRUKTUR NARATIF A.J. GREIMAS DALAM NOVEL LELAKI HARIMAU KARYA EKA KURNIAWAN
}

\section{Herlinda Yuniasti}

Magister Kajian Sastra dan Budaya, Fakultas Ilmu Budaya, Universitas Airlangga, Jalan Dharmawangsa Dalam Selatan, Surabaya 60286, Indonesia

*Corresponding author: herlinda.yuniasti-2018@fib.unair.ac.id

\section{INFORMASI ARTIKEL}

ABSTRAK

\section{Sejarah Artikel}

Diterima: 2/10/2019

Direvisi: $24 / 11 / 2019$

Diterima: 25/11/2019

Tersedia Daring: 30/12/2019

Kata Kunci

Greimas

KDRT

Lelaki Harimau

Naratologi
Penelitian ini membahas novel Lelaki Harimau karya Eka Kurniawan untuk membant pembaca dalam memahami runtutan alur novel serta wacana yang terdapat dalam nove Teori yang dimanfaatkan dalam penelitian ini adalah naratologi A.J. Greimas. Metoc yang digunakan dalam penelitian ini adalah metode deskriptif kualitatif. Sumber da penelitian berasal dari novel Lelaku Harimau karya Eka Kurniawan. Penelitian diawa dengan mengidentifikasi struktur aktan, dilanjutkan dengan menyusun modı fungsional. Analisis terhadap novel ini menunjukkan bahwa alur cerita novel Lelal Harimau secara berurutan adalah Bab III - Bab II - Bab IV - Bab V - Bab I. Selain it hasil analisis juga menggambarkan fenomena kekerasan dalam rumah tangga (KDR] yang dilakukan oleh Komar terhadap Nuraeni. Dengan demikian, dalam bentuk struktı maupun isi, Lelaki Harimau merupakan salah satu novel yang menyuarakan KDR' terhadap perempuan.

\section{ABSTRACT}

Keywords
Domestic violence
Greimas
Man Tiger
Narratology

This article discusses Man Tiger novel by Eka Kurniawan to help the readers i understanding the flow of the plot and the discourse in the novel. This researc used A.J. Greimas perspective of narratology. The method used in this researc was the descriptive qualitative method. It began with identifying the structure $c$ the actants, followed by compiling a functional model. From the analysis result, was found that the storyline of Man Tiger in sequence is Chapter III - Chapter - Chapter IV - Chapter V - Chapter I. Besides, the results also describe th domestic violence phenomenon perpetrated by Komar against Nuraeni. Man Tige is one of the novels that voiced domestic violence against women.

Copyright@2019, Herlinda Yuniasti This is an open access article under the $\mathrm{CC}-\mathrm{BY}-3.0$ licens

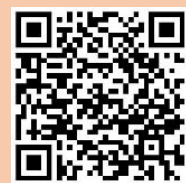

\section{PENDAHULUAN}

Pada 2016 lalu, untuk pertama kalinya penulis Indonesia masuk dalam nominasi The Man Booker International Prize. Penulis tersebut adalah Eka Kurniawan dengan novelnya yang berjudul Man Tiger. Novel ini merupakan novel Lelaki Harimau versi Bahasa Inggris yang diterjemahkan Labodalih Sembiring pada 2015. Walau tidak sampai memenangkan penghargaan tersebut, masuknya Eka Kurniawan dalam daftar nominasi merupakan kebanggaan tersendiri bagi Indonesia.

Eka Kurniawan adalah penulis Indonesia yang sudah menerbitkan beberapa novel dan kumpulan cerita pendek. Karya-karyanya itu seperti Cantik Itu Luka (2002), Seperti Dendam, Rindu Harus Dibayar Tuntas (2014), O, Tentang Seekor Monyet yang Ingin Menikah dengan Kaisar Dangdut (2016), Corat-coret di Toilet (2000), Cinta Tak Ada Mati (2005), dan Perempuan Patah Hati yang Kembali Menemukan Cinta Melalui Mimpi (2015). Beberapa di antaranya sudah diterjemahkan ke dalam bahasa Jepang, Malaysia, Perancis, Italia, Belanda, 
Jerman, Korea, dan Inggris. Tak terkecuali novel Lelaki Harimau (Noviyanti \& Dermawan, 2018).

Lelaki Harimau pertama kali diterbitkan pada 2004. Novel ini mengisahkan permasalahan keluarga yang menyebabkan pembunuhan. Margio, tokoh utama dalam novel ini membunuh Anwar Sadat dengan tragis (Apriani, 2017). Namun Margio tidak mengakui bahwa dia telah membunuh orang. Diakuinya, pembunuh sebenarnya adalah harimau putih dalam tubuhnya. Harimau putih dalam novel ini dipercaya sebagai binatang sakti yang dapat melindungi pemiliknya dari segala bahaya. Novel ini menarik untuk dikaji karena memiliki alur yang tidak berurutan (Apsari, 2017). Pembukaan diawali dengan cerita pembunuhan yang dilakukan oleh Margio, dan diakhiri dengan penyebab Margio membunuh Anwar Sadat. Novel ini tidak dapat dibaca dengan cepat karena diceritakan secara melompat-lompat di setiap babnya. Untuk membantu pembaca dalam memahami runtutan alur tersebut, maka digunakanlah teori naratologi A.J Greimas (Salahuddin, 2018). Pemahaman terhadap teks ini sangat diperlukan untuk memberikan landasan pembacaan tahap berikutnya, salah satunya berguna untuk mengetahui wacana yang terdapat dalam teks (Fatimah, Supriadi, \& Komarudin, 2018).

Naratologi mempunyai ruang lingkup rangkaian peristiwa, relasi antarperistiwa, cara penyajian peristiwa, sudut pandang penceritaan, dan pencerita/narrator. Naratologi A.J Greimas dibangun berdasarkan asumsi dasar bahwa teks naratif tersusun dari analogi-analogi struktural dalam linguistik yang bersumber dari Saussure, serta teori naratif Vladimir Propp yang mengutamakan pada dongeng (Rahmah, 2015). Greimas meringkas konsep Propp mengenai 31 fungsi menjadi 20 fungsi dalam 3 sintagma. Greimas juga menawarkan konsep aktan. Aktan adalah sesuatu yang abstrak dan terbentuk atas tindakan. Aktan dihubungkan dengan satuan sintaksis yang mempunyai fungsi tertentu. Fungsi dapat diartikan sebagai satuan dasar cerita yang menerangkan tindakan bermakna sehingga membentuk narasi (Karnanta, 2015). Aktan menurut Greimas ada enam, yaitu subjek, objek, pengirim, penerima, pembantu, dan penentang. Greimas juga berusaha menemukan pola teks naratif yang menitikberatkan pada fungsi tokoh sebagai aktan yang menggerakkan suatu cerita dalam suatu struktur relasi sintagmatik (Fatimah et al., 2018).

Selain itu, Greimas juga mengemukakan model fungsional, yaitu model cerita sebagai alur. Model fungsional bertugas menguraikan tugas objek dalam rangka melaksanakan tugas pengirim yang terdapat dalam aktan. Skema fungsional dibagi menjadi tiga tahap, yaitu Situasi awal, Transformasi (terdiri dari tahap kecakapan, tahap utama, dan tahap kegemilangan), dan Situasi akhir. Teori AJ Greimas dipilih untuk menghubungkan tokoh-tokoh dalam novel Lelaki Harimau melalui skema aktansial dan struktur fungsional melalui pola cerita (Wijayanti, Hadi, \& Furinawati, 2018).

Lelaki Harimau telah dikaji oleh beberapa peneliti dari perspektif yang berbeda-beda. Di antaranya adalah penelitian berjudul Kekerasan terhadap Tokoh Perempuan dalam Novel Seperti Dendam Rindu Harus Dibayar Tuntas dan Lelaki Harimau Karya Eka Kurniawan oleh (Prasetyo \& Haryadi, 2017). Lalu penelitian milik Apriani (2017) berjudul Penokohan, Latar, dan Tema dalam Novel Lelaki Harimau Karya Eka Kurniawan: Analisis Struktur Novel Model Robert Stanton. Dilanjutkan dengan penelitian oleh Apriyanto (2015) yang meneliti Ketidakadilan Gender dalam Novel Lelaki Harimau. Penelitian selanjutnya dilakukan oleh Nugraha (2019) yang berjudul Konflik Sosial pada Novel Lelaki Harimau Karya Eka Kurniawan. Dari keempat penelitian tersebut dapat dilihat bahwa penelitian Lelaki Harimau dari sudut pandang A.J Greimas masih belum dilakukan. Pengkajian novel Lelaki Harimau menggunakan teori naratologi A.J Greimas bertujuan untuk menganalisis struktur serta mengeksplorasi peran tokoh dan keterlibatannya dalam setiap peristiwa. Teori ini akan mengungkap skema aktansial dan struktur fungsional novel. Dengan mengungkapkan hal ini, 
akan membuat pembaca memahami alur cerita novel dan dapat menceritakan kembali secara runtut.

\section{METODE}

Sesuai dengan tujuan dan permasalahan yang dipaparkan, maka metode yang digunakan dalam penelitian adalah metode deskriptif. Metode ini digunakan untuk mendeskripsikan dan menginterpretasi data-data yang tertulis dalam novel Lelaki Harimau karya Eka Kurniawan. Sumber data dalam penelitian ini adalah novel Lelaki Harimau karya Eka Kurniawan yang diterbitkan oleh Gramedia Pustaka Utama pada tahun 2014. Data dalam penelitian ini mencakup satuan cerita yang terwujud dalam dialog, monolog, paragraf, sekuen cerita, bagian kalimat, maupun narasi tokoh yang menunjukan masalah sesuai dengan tujuan penelitian. Teknik pengumpulan data yang dilakukan adalah menggunakan teknik studi dokumentasi. Teknik ini dilakukan berdasarkan tujuan penelitian.

Pengumpulan data dilakukan dengan teknik studi dokumentasi atau studi kepustakaan dengan disertai pemahaman arti secara mendalam (sinverstehen) dan pemerian mendalam (thick description). Analisis data diawali dengan mengidentifikasi struktur aktan dan model fungsional dalam cerita dengan membaca keseluruhan isi cerita. Kemudian menentukan struktur aktan dengan cara melakukan analisis tidakan tokoh dalam cerita, sehingga dapat ditemukan perannya. Struktur aktan yang ditentukan berupa subjek, objek, penentang, penolong, dan penerima. Setelah itu, analisis dilanjutkan dengan menyusun model fungsional melalui analisis terhadap pergerakan cerita yang dibagi menjadi tiga bagian (situasi awal, transformasi, situasi akhir). Langkah-langkah yang dilakukan dalam proses analisis data sesuai dengan rancangan analisis data yang dipaparkan oleh Miles dan Huberman (Creswell, 2014). Model analisis data yang digunakan adalah flow model of analysis yang prosesnya dilakukan dengan langkah-langkah (1) penyeleksian data, (2) pemaparan data, dan (3) penarikan kesimpulan.

\section{HASIL DAN PEMBAHASAN HASIL}

Novel Lelaki Harimau menceritakan tentang permasalahan keluarga dalam masyarakat. Tokoh utama bernama Margio, yang pendendam sekaligus penyayang. Margio mempunyai ayah bernama Komar Bin Sueb yang berperangai buruk dan sering melakukan kekerasan pada istri dan anak-anaknya. Kekerasan tersebut memicu kebencian Margio pada Komar. Margio berusaha membahagiakan ibunya, Nuraeni. Usaha tersebut termasuk menyuruh ibunya menikah lagi setelah ditinggal mati oleh Komar. Karena tidak menerima kasih sayang dari Komar, Nuraeni berselingkuh dengan Anwar Sadat, lelaki jebolan universitas seni yang religious sekaligus sering main perempuan. Mereka berselingkuh hingga Nuraeni hamil adik Margio, Marian. Anwar Sadat sudah beristri dan mempunyai 3 anak perempuan, yang salah satunya adalah kekasih Margio, bernama Maharani. Karena itulah, Margio tidak bisa meneruskan hubungannya dengan Maharani. Akhirnya Komar meninggal dan Margio membunuh Anwar Sadat dengan tragis karena menolak menikahi Nuraeni.

Lelaki Harimau mempunyai tokoh utama dan tokoh bawahan. Margio merupakan tokoh utama, sedangkan Komar Bin Sueb, Nuraeni, Anwar Sadat, Mameh, Maharani, Laila, Maesa Dewi, Ayung Yuda, Kaisa, Mayor Sadrah, Kyai Jahro, Ma Robiah, Ma Soma, Ma Muah, dan Marian merupakan tokoh bawahan. Tokoh bawahan membantu Margio membangun cerita dalam novel ini.

Dalam teks ini terdapat beberapa konflik dengan masing-masing skema aktan dan model fungsional di dalamnya. Konflik tersebut yang membangun cerita. Dijabarkan bahwa novel ini mengandung 5 Bab. Pada bab pertama diceritakan tentang pembunuhan Anwar Sadat. Pada bab kedua diceritakan tentang kematian Marian dan Komar. Pada bab ketiga diceritakan tentang 
hubungan Komar dan Nuraeni, sekaligus awal dari ketidakberuntungan mereka. Pada bab keempat diceritakan tentang Nuraeni yang berselingkuh dengan Anwar Sadat. Akhirnya, Nuraeni hamil dan melahirkan seorang bayi perempuan. Pada bab kelima, diceritakan tentang alasan pembunuhan Anwar Sadat oleh Margio. Melalui konsep Greimas, dapat diidentifikasi skema aktan serta fungsi dalam teks Lelaki Herimau ini.

\section{PEMBAHASAN}

\section{Skema Aktansial dalam Novel Lelaki Harimau}

Sebelum mengidentifikasi subjek, objek, pengirim, penerima, penolong, dan penentang, berikut adalah definisi dari masing-masing konsep tersebut. Subjek adalah aktan yang mengadakan perjanjian dengan pengirim, yang menganggap bahwa telah menjadi tugasnyalah untuk mendapatkan objek. Objek adalah sesuatu yang diingini pengirim, yang tidak ada pada diri pengirim. Pengirim adalah aktan yang menggerakkan cerita atau yang oleh karenanya suatu cerita dalam suatu struktur naratif dapat tersusun. Pengirim menentukan objek yang dicari dan dia pula yang dapat meminta subjek untuk mendapatkan objek yang dikehendaki. Penerima adalah aktan yang menerima objek. Penolong adalah aktan yang membantu subjek melaksanakan tugasnya. Penolong adalah aktan yang menghalangi tugas subjek untuk mendapatkan objek.

\section{Skema I}

Skema I diambil dari bab I novel Lelaki Harimau yang menceritakan tentang pembunuhan Anwar Sadat. Pada Skema pertama ini, yang bertindak sebagai pengirim adalah hasrat membunuh Margio. Diceritakan bahwa Margio mempunyai hasrat yang sangat besar untuk membunuh orang. Bahkan ketika dihadang oleh Mayor Sadrah karena membawa samurai yang ditentengnya, dia pun menjawab bahwa dia bermaksud membunuh orang.

[...] tak peduli senafsu apa pun Margio ingin membunuh orang, dan semenyebalkan apa pun lelaki yang bernama Anwar Sadat. (Kurniawan, 2004: 4)

"Tapi kau bisa bunuh orang dengan itu jika kau mau," kata Mayor Sadrah. "Itulah Maksudku." (Kurniawan, 2004: 6)

Penerima dalam skema I ini adalah Anwar Sadat dan Komar. Keduanya adalah orang yang sangat dibenci oleh Margio dan ingin dibunuhnya. Namun, yang menjadi objek dalam skema I ini adalah Anwar Sadat. Margio membunuhnya dengan sadis, yaitu menggigitnya seperti seekor harimau menggigit mangsanya.

[...] dan mengajak dirinya membunuh Anwar Sadat. (Kurniawan, 2004: 32)

Saat itulah Margio menancapkan gigi-giginya di leher kiri Anwar Sadat, seperti ciuman kekasih yang membara... (Kurniawan, 2004: 32)

Subjek dari skema ini adalah Margio. Penolong dalam skema ini adalah harimau putih dalam diri Margio. Harimau tersebut menolong Margio untuk melampiaskan hasrat membunuhnya. Sedangkan penentang dalam skema ini adalah Mayor Sadrah dan Agung Yuda. Mayor Sadrah memperingatkan Margio untuk tidak menuruti hasrat membunuhnya. Sebelum pergi ke rumah Anwar Sadat, Margio juga memberitahu Agung Yuda. Agung Yuda merasa menyesal karena tidak menahannya. 
Bagaimanapun Mayor Sadrah punya alasan cukup untuk mencemaskan samurai telanjang yang ditenteng orang di tepi jalan, tak peduli sejinak apa pun benda itu. (Kurniawan, 2004: 6)

Dua puluh menit setelah itu barulah Agung Yuda menyesal telah membiarkannya pergi, serasa ia ditahan tangan nasib bahwa peristiwa itu memang harus terjadi dan tak boleh menghalanginya. (Kurniawan, 2004: 29) 


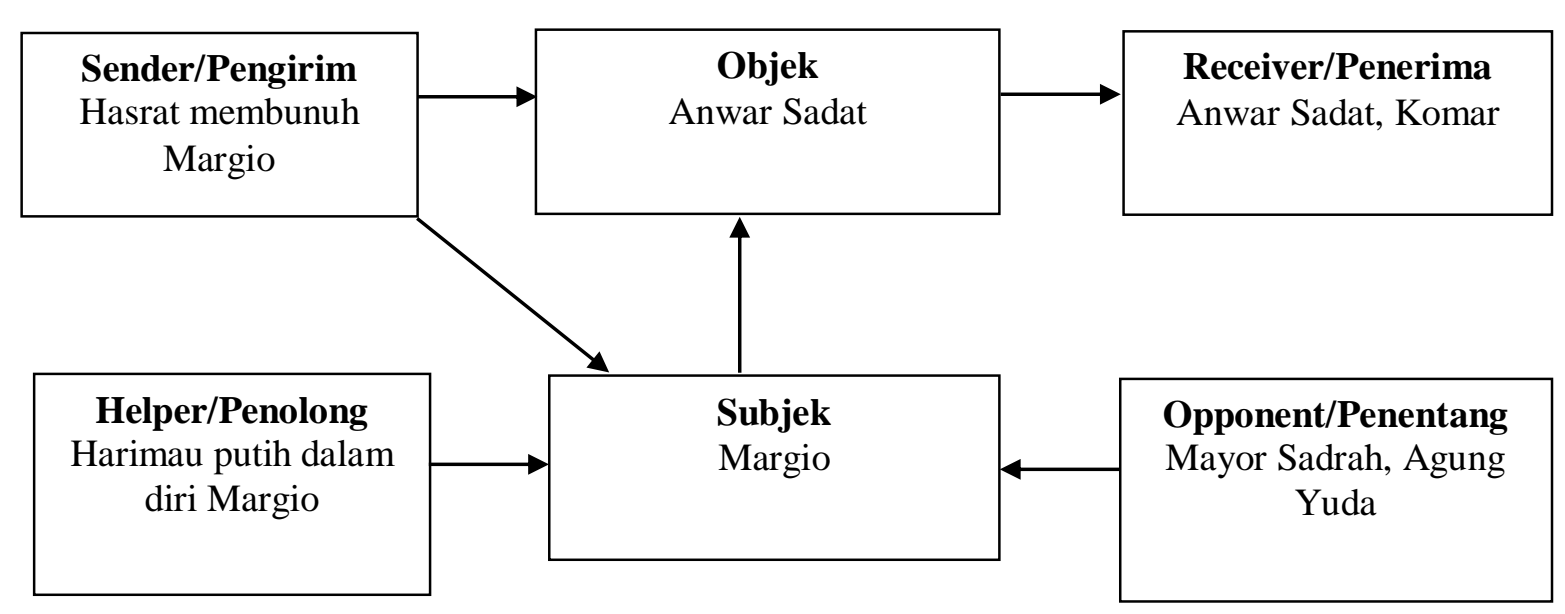

\section{Skema I Relasi Antaraktan Bab I Novel Lelaki Harimau}

\section{Skema II}

Skema II diambil dari bab II novel Lelaki Harimau yang menceritakan tentang kematian Marian dan Komar. Pada Skema pertama ini, yang bertindak sebagai pengirim adalah kepergian Margio dari rumah. Margio pergi dari rumah karena rasa bencinya kepada Komar, terlebih setelah Marian meninggal.

... Margio bilang pada Mameh, "Aku akan pergi." Dan menambahkan, "Jika tidak, aku bakalan membunuh lelaki ini." (Kurniawan, 2004: 61)

Penerima dalam skema ini adalah Komar dan Mameh. Kepergian Margio berdampak pada Komar. Komar menjadi merasa kehilangan dan merasa bersalah, hingga akhirnya meninggal. Dengan kepergian kakaknya, Mameh juga harus mengurus semua sendiri.

Tapi Mameh tahu ia mulai merindukannya, sebab suatu pagi Komar bin Sueb bertanya kepadanya. (Kurniawan, 2004: 62)

Sepanjang waktu-waktu itu sekarat itu, istrinya tak mau ambil urus dirinya, dan Mameh harus menanggung semua kerepotan seorang diri. (Kurniawan, 2004: 63)

Objek dalam skema ini adalah kematian Komar. Setelah kepergian Margio, dia semakin menyibukkan diri dan melakukan banyak hal untuk mengabaikan kepergian anak sulungnya itu. Namun, lama kelamaan dia menjadi sakit, sekarat, dan meninggal.

Rasa kehilangan itu rupanya tidak main-main, sebab ia mulai tak beranjak dari tempat tidur, kurus tak karuan dan mengigau tak ada henti. (Kurniawan, 2004: 63)

Subjek dari skema ini adalah Margio. Margio berperan penting dalam jalan cerita bab II ini. Kebencian Margio terhadap Komar membuatnya pergi dari rumah. Kepergiannya pun menyebabkan kematian Komar. Penolong dalam skema ini adalah kematian Marian dan Mameh. Kematian Marian membuat Margio semakin membenci Komar karena Komar tidak mempedulikan Marian sejak dia lahir. Mameh juga mendukung Margio, karena kepergiannya membuat Komar meninggal. Mameh sangat senang atas kematian Komar karena dulu Komar 
pernah memergokinya bugil. Sedangkan penentang dalam skema ini adalah Nuraeni. Nuraeni memang membenci Komar. Namun saat Komar meninggal, Nuraeni masih menangis dan bersedih.

Sepanjang tahun-tahun yang lewat, ia masih bisa menahannya, hingga malam ketika Marian adik bungsunya mati. Itulah yang membikin ia tak terkendali, dan kepada Mameh berkata hendak menghentikan hidup Komar bin Sueb. (Kurniawan, 2004: 55)

Maka kematian Komar membangkitkan rasa senang pada Mameh, rasa senang yang bagi dirinya sendiri aneh. (Kurniawan, 2004: 73)

Dalam keheningan itu, Mameh mendengar semacam isak tangis, sedu kecil, tak meragukan itu datang dari mulut ibunya, di tengah gumaman tak ada makna. Betapa mengejutkan itu bagi Mameh, menyadari perempuan itu bisa bersedih pada suami yang sepanjang hidupnya dihabiskan untuk memukuli dirinya, untuk salah ini dan salah itu dan tanpa salah sama sekali. (Kurniawan, 2004: 67-68)

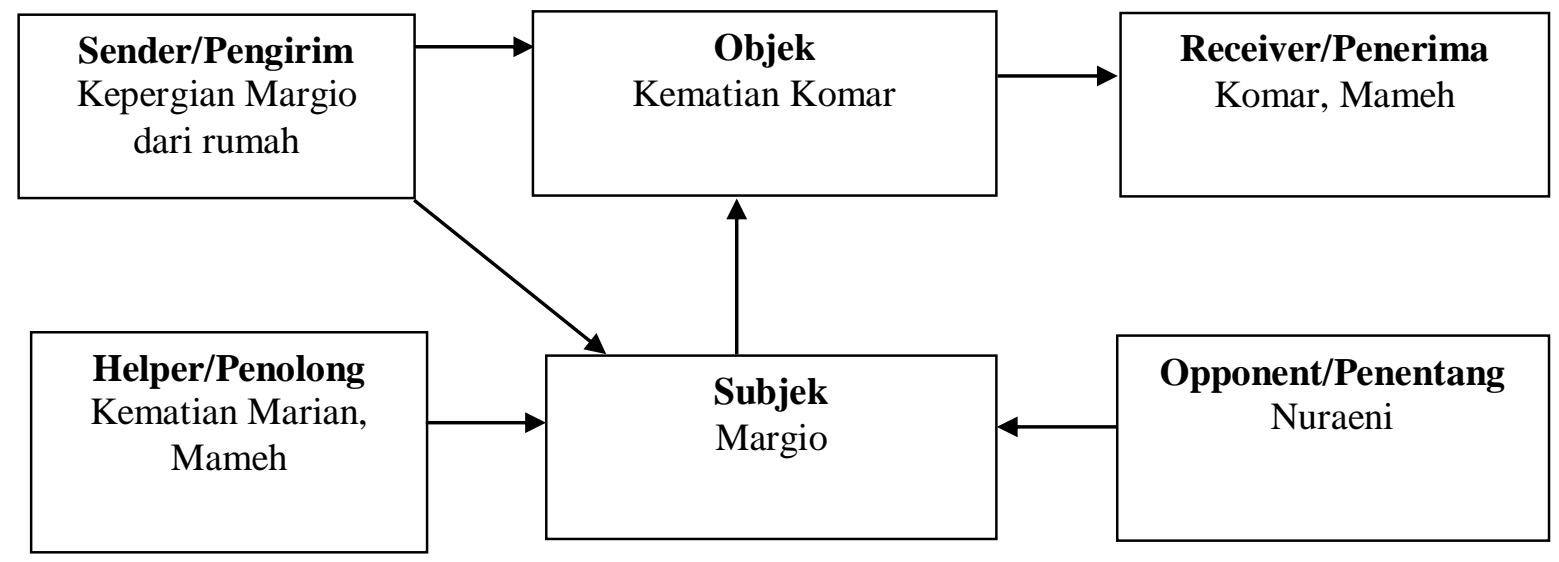

\section{Skema II Relasi Antaraktan Bab II Novel Lelaki Harimau}

\section{Skema III}

Skema III diambil dari bab III novel Lelaki Harimau yang menceritakan tentang hubungan Komar dan Nuraeni, sekaligus awal dari ketidakberuntungan mereka. Pada Skema pertama ini, yang bertindak sebagai pengirim adalah kepindahan keluarga Komar ke tanah dan rumah Ma Rabiah yang murah. Setelah menikah, Komar dan Nuraeni tinggal di sepetak rumah yang berdiri di tepi perempatan jalan koral, yang seminggu sekali menjelma menjadi Pasar Senin. Kemudian mereka pindah ke rumah 131 yang tanahnya dimiliki oleh Ma Rabiah. Ma Rabiah menjualnya dengan sangat murah karena sakit hati dengan pewarisnya. Akhirnya, tanah tersebut dibeli oleh Komar setelah delapan tahun tinggal di sana. Penerima dalam skema ini adalah seluruh keluarga Komat, termasuk Nuraeni, Mameh, dan Margio. Mau tidak mau, mereka pindah dari rumah sebelumnya yang tidak layak, ke rumah Ma Rabiah.

Subjek dalam skema ini adalah Komar. Komar berusaha untuk mencarikan rumah yang lebih layak ditinggali keluarga mereka. Objek dari skema ini adalah Nuraeni. Awalnya Nuraeni kecewa dengan rumah baru mereka. Seiring berjalannya waktu, ternyata Nuraeni semakin tidak bergairah untuk tinggal di rumah itu. Nuraeni menjadi semakin kusut dan tidak bergairah. Nuraeni bahkan mulai berbicara dengan kompor dan panci di dapur rumah mereka. 
“Kujual semurah mungkin.” (Kurniawan, 2004: 91)

"Di sinilah kita tinggal, menunggu Ma Rabiah mengusir dan kita mesti melipat semua ini," kata Nuraeni tak lama selepas mereka membersihkan rumah dengan sia-sia. (Kurniawan, 2004: 88)

Gairah itu tak juga datang. Nuraeni hanya pergi ke dapur, begitulah kelakuannya belakangan itu jika hendak melarikan diri dan tak hendak bersuara untuk lelakinya. (Kurniawan, 2004: 95)

Penolong dalam skema ini adalah Ma Rabiah. Ma Rabiah menolong Komar untuk mendapatkan tanah dan rumah yang ditempatinya karena sakit hati kepada ahli warisnya. Lalu penentang dalam skema ini adalah kekecewaan Nuraeni pada Komar. Nuraeni sudah kecewa kepada Komar sejak sebelum pernikahan mereka. Rasa cintanya kepada Komar sudah tidak ada karena dia tidak mengiriminya surat. Terlebih mengetahui Komar adalah seorang tukang cukur. Kekecewaan itu dilanjutkan setelah mereka akhirnya tinggal di rumah yang tidak layak. Inilah yang menghalangi Komar untuk membahagiakan Nuraeni.

Sakit hati pada bocah-bocah itu, ia mulai berpikir mencari cara untuk tak memberi mereka apa pun yang dimilikinya. Kepada beberapa orang, tanpa canda ia berkata, "Carikan aku cara mencabut mereka sebagai ahli warisku." (Kurniawan, 2004: 91)

Jadi ia pergi jauh hanya jadi tukang cukur, pikir Nuraeni. Ia tak peduli dengan itu, bahkan seandainya Komar ternyata perampok, tukang pukul, preman, dan maling, semuanya tak berarti apa lagi setelah satu tahun yang membinasakan rasa cinta meluap itu. (Kurniawan, 2004: 109-110)

Bahkan meskipun kemudian mereka berhasil memilikinya, itu sama sekali tak menghentikan percakapan Nuraeni dengan benda-benda di dapur. (Kurniawan, 2004: 114)

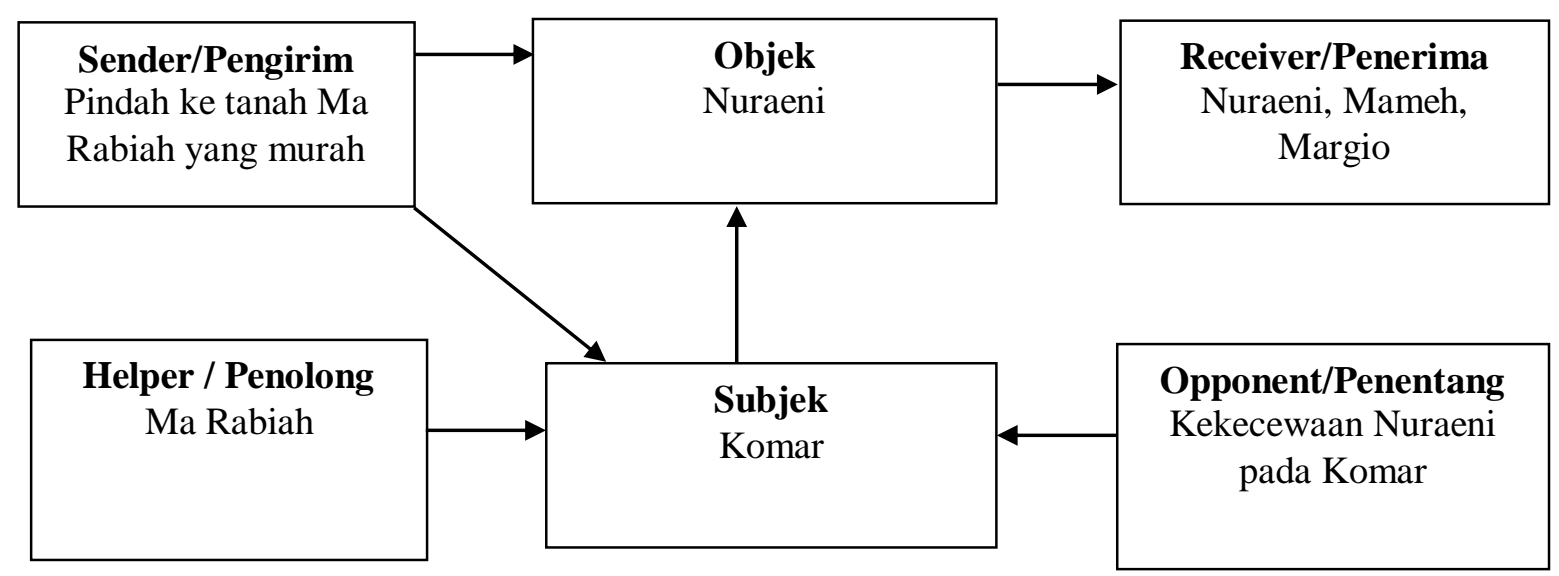

\section{Skema IV}

\section{Skema III Relasi Antaraktan Bab III Novel Lelaki Harimau}

Skema IV diambil dari bab IV novel Lelaki Harimau yang menceritakan tentang Nuraeni yang berselingkuh dengan Anwar Sadat. Karena perselingkuhannya itu, dia hamil dan melahirkan seorang putri. Pada Skema pertama ini, yang bertindak sebagai pengirim adalah 
kekerasan yang dilakukan Komar. Komar tidak hanya melakukan itu kepada Nuraeni, tapi juga kepada anak-anaknya. Hal itu juga menunjukkan bahwa penerima pada skema ini adalah Nuraeni, Margio, Mameh, dan Marian.

Sepanjang hidupnya, ia telah sering melihat Komar memukul Nuraeni di depan matanya sendiri, menghajarnya hingga babak belur. Margio terlampau kecil untuk melerai, dan ia sendiri sering dapat bagiannya pula. (Kurniawan, 2004: 115)

Mereka menjalani hari yang murung, saat-saat yang damai hanyalah ketika Komar pergi dengan sepedanya ke kios cukur di pasar hingga waktu pulang datang. Bahkan Mameh yang tak banyak polah, sekali waktu dapat juga pukulan rotan penggebuk kasur itu, sebagaimana kucing lewat sekali dua dihajarnya pula. (Kurniawan, 2004: 117)

Subjek dari skema ini adalah Nuraeni. Akibat dari KDRT Komar, Nuraeni berselingkuh dengan Anwar Sadat. Perselingkuhannya itu bermula ketika dia bekerja di rumah Anwar Sadat. Dari hasil perselingkuhannya itu, Nuraeni hamil. Perselingkuhan dan kehamilan ini membuat Nuraeni semakin cantik dan merias diri. Nuraeni sesungguhnya ingin melihat kehancuran dan kematian Komar. Inilah yang menjadi objek di skema ini.

[...] Nuraeni merayakan kehancuran usaha Komar dengan mendesus-desuskannya bersama bebanda di dapur. (Kurniawan, 2004: 118)

Nuraeni tampaknya berharap membuat rumah itu seburuk yang bisa dipikirkannya, seremuk sebagaimana dikatakannya waktu pertama kali datang ke 131. (Kurniawan, 2004: 122)

Itu sama sekali tak membikinnya panik, malahan tambah membuatnya suka, [...] (Kurniawan, 2004: 141)

Penolong skema ini adalah Anwar Sadat. Perselingkuhannya dengan Nuraeni tidak diketahui oleh siapa pun, bahkan oleh Kasia, Maesa Dewi, bahkan Laila. Anwar Sadat memperlakukan Nuraeni dengan baik, sehingga Nuraeni menikmati perselingkuhannya dengan Anwar Sadat dan membalas dendam kepada Komar. Margio juga menjadi penolong. Perubahan yang terjadi pada Nuraeni dan lahirnya Marian membuatnya semakin mendukung perselingkuhan Nuraeni dan Anwar Sadat. Lalu penentang dalam skema ini adalah Mameh dan Margio. Mameh merasa perubahan sikap Nuraeni sangatlah aneh. Saat dia mulai menanam bunga alamanda, Nuraeni merawatnya dengan sangat baik bahkan lebih baik dari merawat anaknya sendiri. Margio juga awalnya merasa malu karena mengetahui bayi di dalam perut ibunya adalah benih Anwar Sadat.

Sangatlah jelas Anwar Sadat seorang penyabar dalam bercinta. (Kurniawan, 2004: 139)

... Hanya Anwar Sadat yang merasakannya, terpesona bisa membuat perempuan itu menjadi pengantin baru sepenuhnya, dan ia akan menyediakan dirinya untuk Nuraeni ... (Kurniawan, 2004: 141) 
"Lihatlah, Komar," gumam Margio, "Wajahnya terkutuk sangat bahagia." (Kurniawan, 2004: 152)

Anak nakal ini juga disiraminya, kadang Mameh berpikir ia mengurusnya lebih telaten daripada kepada anak kandungnya sendiri. (Kurniawan, 2004: 119)

Ada rasa malu membuncah di dirinya, dan menuntunnya pergi dari rumah, terdampar di pos ronda, dan terus merenungi semua itu sebab ke mana pun pikirannya pergi, kenyataan tersebut demikian gambling di depan matanya. (Kurniawan, 2004: 144)

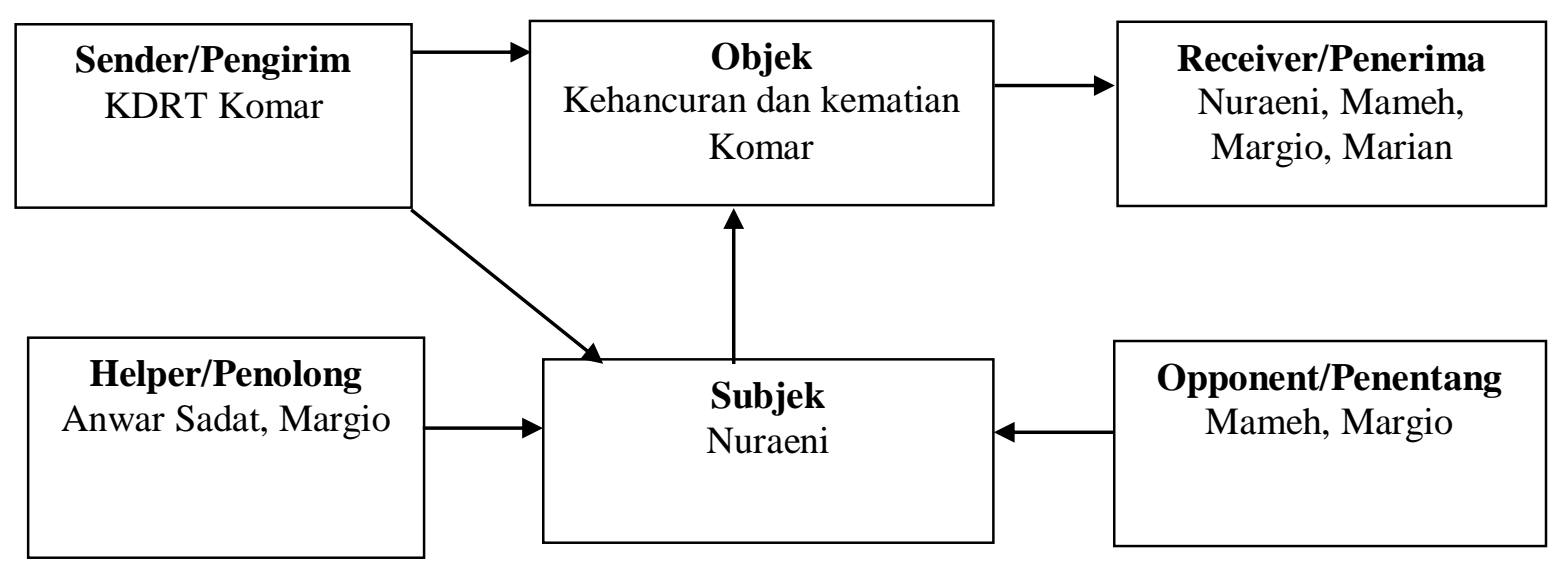

\section{Skema $V$}

\section{Skema IV Relasi Antaraktan Bab IV Novel Lelaki Harimau}

Skema V diambil dari bab V novel Lelaki Harimau yang menceritakan tentang alasan pembunuhan Anwar Sadat oleh Margio. Pada Skema pertama ini, yang bertindak sebagai pengirim adalah kemarahan Margio. Margio marah karena ternyata Anwar Sadat tidak berniat menikahi Nuraeni. Penerima dalam skema ini adalah Maharani. Kenyataan bahwa Nuraeni hamil benih Anwar Sadat membuat Margio tidak bisa menerima cinta Maharani.

Tergagap Anwar Sadat menggeleng, dan dengan kata terpatah ia bergumam. "Tidak mungkin, kau lihat aku ada istri dan anak." Tatapan itu jelas mencela gagasan konyol Margio. Dan kalimat selanjutnya memberi penjelasan melimpah, "Lagipula aku tak mencintai ibumu." (Kurniawan, 2004: 190)

Jelaslah itu pun sanggup menghentikan tangis si gadis, yang kini menganga dengan kata-kata yang bangsat dan tak sanggup dicernanya. (Kurniawan, 2014)

... Diam tak bicara, tak menyentuh makan malam, mengurung diri di kamar, sebelum pagi datang dan berkata ia hendak pergi. (Kurniawan, 2004: 187)

Subjek dari skema ini adalah Margio. Dalam bab V ini, Margio menjadi penggerak cerita. Dia kehilangan gadis yang disukainya demi kebahagiaan ibunya. Namun Anwar Sadat sebagai objek dalam skema ini ternyata menolak menikahi ibunya. Sedangkan penolong dalam skema ini adalah harimau putih dalam diri Margio dan bayangan perasaan Komar. Harimau putih itu langsung keluar setelah Margio mendengar penolakan Anwar Sadat untuk menikahi Nuraeni. Margio juga kasihan kepada Komar yang sudah mati. Penentang dalam skema ini adalah 
Nuraeni. Nuraeni sangat menyayangi Marian. Hal ini yang menentang Margio membunuh Anwar Sadat dan membuatnya menyuruh Anwar Sadat untuk menikahi Nuraeni.

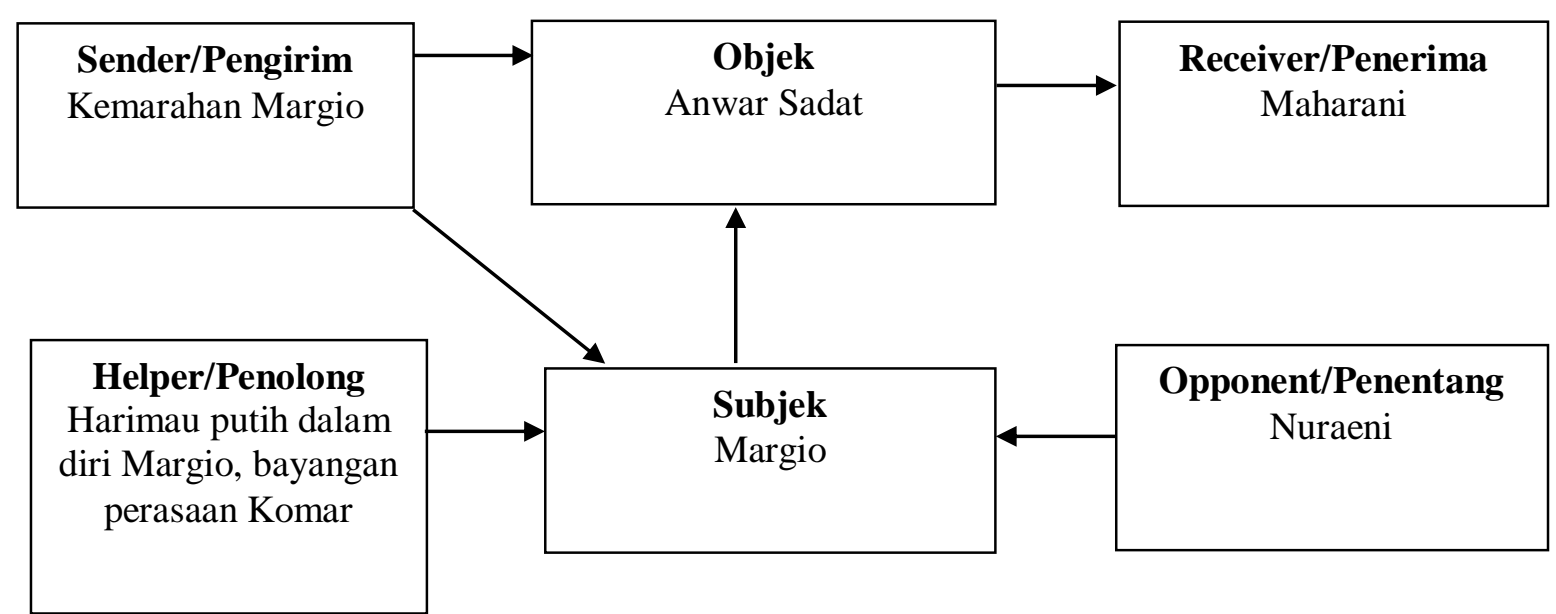

Skema V Relasi Antaraktan Bab V Novel Lelaki Harimau

\section{Skema Model Fungsional dalam Novel Lelaki Harimau}

Setelah membagi skema aktansial menjadi lima, dapat diketahui bahwa ternyata peristiwa antarbab tidak berurutan. Model fungsional menunjukkan formula cerita sebagai pola peristiwa-peristiwa yang disebut fungsi. Model fungsional adalah skema yang menunjukkan pergerakan cerita dari situasi awal ke situasi akhir. Ini akan membantu pembaca novel Lelaki Harimau untuk melihat urutan alur cerita yang sebenarnya.

\section{Situasi Awal}

Situasi awal adalah kondisi adanya keinginan untuk mendapat sesuatu. Dalam novel Lelaki Harimau, situasi awal ditandai dengan perkenalan Komar bin Sueb dan Nuraeni. Mereka Kemudian menikah, mempunyai anak, dan tinggal di rumah 131. Cerita ini terdapat pada Bab III novel ini.

\section{Transformasi}

Tahap kecakapan adalah adanya keberangkatan subjek, munculnya penentang dan penolong. Dalam novel ini, tahap kecakapan ditandai oleh kematian Komar. Cerita ini terdapat pada Bab II novel ini.

Tahap utama adalah adanya pergeseran ruang dan waktu, dalam arti pahlawan telah berhasil mengatasi tantangan dan melakukan perjalanan kembali. Perselingkuhan Nuraeni dengan Anwar Sadat yang membuatnya hamil Marian. Cerita ini terdapat pada Bab IV novel ini.

Taham kegemilangan adalah kedatangan pahlawan asli, terbongkarnya tabir dan hukuman bagi pahlawan palsu, dan jasa bagi pahlawan asli. Dalam novel ini, tahap kegemilangan ditandai oleh penolakan Anwar Sadat menikah dengan Nuraeni dan berpisahnya Margio dengan Maharani, anak bungsu Anwar Sadat. Cerita ini terdapat pada Bab V novel ini.

\section{Situasi Akhir}

Situasi akhir dalam novel Lelaki Harimau ini adalah ketika Margio masuk penjara setelah membunuh Anwar Sadat. Hal ini terdapat pada Bab I novel ini. 


\section{SIMPULAN}

Berdasarkan hasil analisis naratif AJ Greimas terhadap novel Lelaki Harimau karya Eka Kurniawan, dapat disimpulkan bahwa ada lima aktan yang terbagi dalam lima bab di novel ini. Diketahui pula bahwa alur dari novel ini tidak berurutan, sehingga dibutuhkan model fungsional untuk membantu analisis alur cerita. Alur cerita hasil analisisnya secara berurutan adalah Bab III - Bab II - Bab IV - Bab V - Bab I. Berdasarkan hasil analisis juga bisa dilihat bahwa struktur aktan dan fungsional dalam novel Lelaki Harimau sudah kompleks dan sudah memenuhi semua tahapannya.

Hasil analisis juga menunjukkan bahwa tokoh perempuan di novel ini berperan penting dalam menggerakkan cerita. Aktan-aktan tokoh perempuan selalu muncul di setiap skema di novel ini. Kekerasan dalam rumah tangga (KDRT) yang dilakukan oleh tokoh Komar terhadap tokoh Nuraeni digambarkan jelas pada skema aktan ketiga, saat Nuraeni menjadi objek KDRT yang dilakukan Komar. Komar melakukan KDRT setelah menikahi Nuraeni. Oleh karena itu, Nuraeni mencari kebahagiaan lain yang tidak didapatkannya dari Komar. Nuraeni menjadi subjek pada skema keempat, saat ia mencari pelarian dengan cara berselingkuh. Namun pada akhirnya, Nuraeni tetap tidak mendapatkan kebahagiaannya itu karena anak hasil perselingkuhannya meninggal, dan selingkuhannya tidak mau menikahinya. Dengan demikian, berdasarkan struktur dan isinya, novel karya Eka Kurniawan ini merupakan salah satu novel yang menyuarakan dan menggambarkan KDRT dan dampaknya terhadap perempuan sebagai korban.

\section{DAFTAR PUSTAKA}

Apriani, E. R. (2017). Penokohoan, Latar, dan Tema dalam Novel Lelaki Harimau Karya Eka Kurniawan: Analisis Struktur Novel Model Robert Stanton (Doctoral Dissertation not Publish), Universitas Gadjah Mada, Yogyakarta.

Apriyanto, D. N. (2015). Ketidakadilan Gender dalam Novel Lelaki Harimau Karya Eka Kurniawan (Doctoral Dissertation not Publish), Universitas Airlangga Surabaya

Apsari, L. (2017). Attitude Analysis Surrounding Gender-Related Words in Lelaki Harimau. International Journal of Languages, Literature and Linguistics, 3(3), 103-109.

Creswell, J. W. (2014). Research Design: Qualitative, Quantitative and Mixed Methods Approaches. Thousand Oaks, CA: Sage Publications Inc.

Fatimah, N., Supriadi, D., \& Komarudin, E. (2018). Struktur Naratif Cerpen "Al-Imra'at Ghalabati As-Syaiton" Karya Taufiq El-Hakim (Kajian Naratologi AJ Greimas). HijaiJournal on Arabic Language and Literature, 1(1), 64-79.

Karnanta, K. Y. (2015). Perempuan yang Mengundang Maut: Analisa Struktur Naratif AJ Greimas pada Film Air Terjun Pengantin. PARAFRASE: Jurnal Kajian Kebahasaan \& Kesastraan, 15(1), 17-25.

Kurniawan, E. (2014). Lelaki Harimau. Jakarta: Gramedia Pustaka Utama.

Noviyanti, P. B., \& Dermawan, R. N. (2018). Konflik Batin Tokoh Utama pada Novel Lelaki Harimau Karya Eka Kurniawan: Pendekatan Psikologi Sastra CARAKA, 5(1), 174-196.

Nugraha, A. A. (2019). Konflik Sosial pada Novel Lelaki Harimau Karya Eka Kurniawan Paper presented at the Prosiding Seminar Nasional Bahasa dan Sastra Indonesia (SENASBASA).

Prasetyo, Y., \& Haryadi, H. (2017). Kekerasan terhadap Tokoh Perempuan dalam Novel Seperti Dendam Rindu Harus Dibayar Tuntas dan Lelaki Harimau Karya Eka Kurniawan. Seloka: Jurnal Pendidikan Bahasa dan Sastra Indonesia, 6(2), 152-160.

Rahmah, Y. (2015). Sanmai No Ofuda dalam Perspektif Greimas. Izumi, 4(1), 28-36. 
Salahuddin, N. (2018). Skema Aktan dan Model Fungsional Novel Maryamah Karpov: Kajian Naratologi AJ Greimas. (Doctoral Dissertation Not Publish), Universitas Negeri Makassar Makassar.

Wijayanti, C. T., Hadi, P. K., \& Furinawati, Y. (2018). Dominasi Laki-Laki Atas Perempuan terhadap Kehidupan Seksual dalam Novel Lelaki Harimau Karya Eka Kurniawan Widyabastra: Jurnal Ilmiah Pembelajaran Bahasa dan Sastra Indonesia, 6(1), 52-61. 